\title{
PENGETAHUAN HAID PADA REMAJA DI MANADO
}

\author{
${ }^{1}$ Freddy Kujangke \\ ${ }^{2}$ Rudy A Lengkong \\ ${ }^{2}$ Eddy Suparman
}

\author{
${ }^{1}$ Kandidat SKRIPSI Fakultas Kedokteran Universitas Sam Ratulangi Manado \\ ${ }^{2}$ Bagian Obstetri dan Ginekologi Fakultas Kedokteran Universitas Sam Ratulangi Manado \\ Email: paai_manado@yahoo.com
}

\begin{abstract}
Backgrounds Dysmenorrhea is the most common gynecological symptom reported in adolescents. Prevalence estimates vary from $45 \%$ to $75 \%$. Absenteeism from work and school as a result of dysmenorrhoea is common (13\% to $51 \%$ women have been absent at least once and $5 \%$ to $14 \%$ are often absent owing to the severity of symptoms). Dysmenorrhea association with psychologist and behavior factors and its effects their physical activities and school performance. Some studies had shown that association between school performance with dysmenorrhea.Objective To assess the comparison between school performance with and without dysmenorrhea in pubertal adolescents. Methods A cross sectional study was conducted on Juni 2010.The samples were recruited with simple randomization in adolescents aged 10 until 18 years old at school of Musthafawiyah Mandailing Natal districs. All subjects who met the inclusion criteria were assessed their school performance on 2 consecutive semester in one year. In order to assessed the comparison between school performance with or without dysmenorrhea used $X 2$ test. Results One hunderd and sixteen subject were participated in this study. After measured the school performance. No significant different on school performance with and without dysmenorrhea in two group $(\mathrm{P}=0.176$ and $\mathrm{P}=008$, $95 \%$ CI -0.05 to 0.05 ). Conclusion: There was no significant difference school performance between with and without dysmenorrheal.
\end{abstract}

Keywords: Dysmenorrhea, school performance, pubertal adolescent.

\begin{abstract}
Abstrak: Latar belakang Nyeri haid merupakan nyeri yang terjadi selama masa menstruasi.Angka kejadian nyeri haid berkisar antara $45 \%$ sampai $75 \%$ dari seluruh remaja perempuan pubertas. Dimana ketidak hadiran di sekolah berkisar antara 13\% sampai $51 \%$ serta 5\% sampai $14 \%$ ketidak hadiran tersebut disebabkan beratnya gejala yang terjadi. Nyeri haid berhubungan dengan faktor perilaku dan psikologis. Selain itu dapat menyebabkan pembatasan aktifitas sekolah dan prestasi akademik. Beberapa studi telah menunjukkan adanya kaitan prestasi akademik dengan nyeri haid. Tujuan Untuk mengetahui perbandingan prestasi akademik dengan dan tanpa nyeri haid pada anak perempuan pubertas. Metode Studi ini merupakan studi cross sectional. Pemilihan sampel secara acak sederhana yang dilakukan pada anak remaja perempuan yang berusia 10 sampai 18 tahun di SMP St Theresia Malalayang dan SMA St Theresia Malalayang Manado yang dilakukan pada bulan Desember 2011. Semua subjek yang memenuhi kriteria inklusi dinilai prestasi akademik selama dua semester berturut-turut.Untuk menilai perbandingan prestasi akademik dengan atau tanpa nyeri haid digunakan uji $X 2$. Hasil Seratus enam belas subjek berpartisipasi dalam penelitian ini. Setelah dinilai prestasi akademik. Ditemukan bahwa tidak terdapat perbedaan yang bermakna antara prestasi akademik dengan atau tanpa nyeri haid (P 0.176 vs P: 0.08 ). IK 95\%:-0.05; 0.05. Simpulan: Tidak ditemukan adanya hubungan prestasi akademik dengan dan tanpa nyeri haid.
\end{abstract}

Kata kunci: Nyeri haid, prestasi akademik, perempuan pubertas 
Pada umumnya remaja didefinisikan sebagai masa peralihan dari masa kanakkanak ke masa dewasa. Batasan usia remaja menurut WHO (badan PBB untuk kesehatan dunia) adalah 12 sampai 24 tahun. Masa remaja merupakan peralihan masa kanak-kanak menjadi dewasa yang melibatkan perubahan berbagai aspek seperti biologis, psikologis, dan sosial budaya. Rentang usia remaja bervariasi bergantung pada budaya. Di Indonesia berbagai studi pada kesehatan reproduksi remaja mendefinisikan remaja sebagai orang muda berusia 15-24 tahun. Sedangkan menurut Badan Koordinasi Keluarga Berencana Nasional (BKKBN) remaja berusia 10-24 tahun. Sementara Departemen Kesehatan dalam program kerjanya menjelaskan bahwa remaja adalah usia 10-19 tahun. Di dalam kehidupan sehari-hari masyarakat menganggap remaja adalah mereka yang belum menikah dan berusia antara 13-16 tahun, atau mereka yang bersekolah di sekolah menengah pertama (SMP) dan sekolah menengah atas (SMA). Setiap remaja akan mengalami pubertas. Pubertas merupakan masa awal pematangan seksual, yakni suatu periode dimana seorang remaja mengalami perubahan fisik, hormonal, dan seksual serta mampu mengadakan proses reproduksi. Masa remaja merupakan masa yang sangat penting dalam perkembangan seseorang. Perubahan-perubahan yang terjadi pada saat ini sangat mempengaruhi seorang remaja dalam menjalani masa remajanya. Pada remaja putri, usia pubertas diawali dengan Haid atau Menstruasi. Pubertas ialah dimulainya kehidupan seksual dewasa, sedangkan menarke (manarche) adalah dimulainya menstruasi. Periode pubertas terjadi karena kenaikan sekresi hormon gonadotropin oleh hipofisis, perlahan dimulai pada tahun kedelapan kehidupan dan mencapai puncaknya pada saat terjadinya menstruasi yaitu pada usia 11-16 tahun. Pada wanita, kelenjar hipofisis dan ovarium akan mampu menjalankan fungsinya secara penuh apabila dirangsang secara tepat. Masa remaja merupakan salah satu tahap dalam kehidupan manusia yang sering disebut sebagai masa pubertas yaitu masa peralihan dari anak-anak ke masa dewasa. Pada tahap ini remaja akan meng-alami suatu perubahan fisik, emosional dan sosial sebagai ciri dalam masa pubertas, dan dari berbagai ciri pubertas tersebut, menstruasi merupakan perbedaan yang mendasar antara pubertas pria dan pubertas wanita.

\section{METODE}

Penelitian ini adalah suatu penelitian yang menggunakan metode deskriptif. Populasi pada penelitian ini adalah siswi kelas 1 SMP St. Theresia Malalayang, siswi kelas 2 SMP St. Theresia Malalayang, siswi kelas 3 SMP St. Theresia Malalayang, siswi kelas 1 SMA St. Theresia Malalayang, siswi kelas 2 SMA St. Theresia Malalayang, dan siswi kelas 3 SMA St. Theresia Malalayang. Penelitian dilaksanakan selama dua bulan, yaitu dari bulan November sampai Desember 2011, dan dilaksanakan di SMP St. Theresia Malalayang dan SMA St. Theresia Malalayang.

\section{Variabel Penelitian}

Umur pertama kali mendapat Haid/ Menstruasi, Panjang siklus Haid/Menstruasi, Pengetahuan tentang Haid/Menstruasi, dan Umur saat ini.

\section{HASIL}

Hasil penelitian lewat kuesioner yang dijalankan adalah sebagai berikut;

Tabel 1. Karakertistik berdasarkan umur

\begin{tabular}{cccclcl}
\hline Usia (tahun) & \multicolumn{2}{c}{ Siswi SMA } & \multicolumn{2}{c}{ Siswi SMP } & \multicolumn{2}{c}{ Total } \\
\cline { 2 - 7 } & Jumlah & \% & Jumlah & \% & Jumlah & \% \\
\hline $12-15$ & 15 & 14,2 & 49 & 46,6 & 64 & 61 \\
$16-20$ & 41 & 39,0 & 0 & 0 & 41 & 39 \\
$21-24$ & 0 & 0 & 0 & 0 & 0 & 0 \\
\hline Total & 56 & 53,2 & 49 & 46,6 & 105 & $100 \%$ \\
\hline
\end{tabular}


Tabel 2. Distribusi pengetahuan haid berdasarkan usia menarche.

\begin{tabular}{ccccccc}
\hline \multirow{2}{*}{ Usia } & \multicolumn{2}{c}{ Siswi SMA } & \multicolumn{2}{c}{ Siswi SMP } & \multicolumn{2}{c}{ Total } \\
\cline { 2 - 7 } & Jumlah & \% & Jumlah & \% & Jumlah & \% \\
\hline 10 tahun & 6 & 5,7 & 3 & 2,8 & 9 & 8,5 \\
11 tahun & 18 & 17,1 & 22 & 20,9 & 40 & 38,0 \\
12 tahun & 11 & 10,4 & 20 & 19,0 & 31 & 29,5 \\
13 tahun & 9 & 8,5 & 5 & 4,7 & 14 & 13,3 \\
14 tahun & 9 & 8,5 & 0 & 0 & 9 & 8,5 \\
15 tahun & 2 & 1,9 & 0 & 0 & 2 & 1,9 \\
\hline Total & 55 & 52,1 & 50 & 47,4 & 105 & $100 \%$ \\
\hline
\end{tabular}

Tabel 3. Distribusi pengetahuan haid berdasarkan lamanya perdarahan haid.

\begin{tabular}{ccccccc}
\hline \multirow{2}{*}{ Lamanya } & \multicolumn{2}{c}{ Siswi SMA } & \multicolumn{2}{c}{ Siswi SMP } & \multicolumn{2}{c}{ Total } \\
\cline { 2 - 7 } & Jumlah & $\mathbf{\%}$ & Jumlah & \% & Jumlah & \% \\
\hline 2 - 5 hari & 24 & 22,8 & 26 & 24,7 & 50 & 47,6 \\
$5-7$ hari & 22 & 21 & 13 & 12,3 & 35 & 33,3 \\
7 - 9 hari & 9 & 8,5 & 7 & 6,66 & 16 & 15,2 \\
>9 hari & 2 & 2 & 2 & 2 & 4 & 3,8 \\
\hline Total & 54 & 54,3 & 46 & 45,5 & 105 & $100 \%$ \\
\hline
\end{tabular}

Tabel 4. Distribusi pengetahuan haid berdasarkan pola panjangnya siklus haid.

\begin{tabular}{ccccccc}
\hline Panjang (hari) & \multicolumn{2}{c}{ Siswi SMA } & \multicolumn{2}{c}{ Siswi SMP } & \multicolumn{2}{c}{ Total } \\
\cline { 2 - 7 } & Jumlah & \% & Jumlah & \% & Jumlah & \% \\
\hline$<21$ & 4 & 3,8 & 5 & 4,7 & 9 & 8,5 \\
$21-28$ & 44 & 42 & 29 & 27,6 & 73 & 69,5 \\
$29-35$ & 9 & 8,5 & 11 & 10,4 & 20 & 19,0 \\
$>35$ & 0 & 0 & 3 & 2,8 & 3 & 2,8 \\
\hline Total & 57 & 54,3 & 48 & 45,5 & 100 & $100 \%$ \\
\hline
\end{tabular}

Tabel 5. Distribusi Pengetahuan haid berdasarkan keluhan yang sering dialami.

\begin{tabular}{lcccccc}
\hline \multirow{1}{*}{ Keluhan } & \multicolumn{2}{c}{ Siswi SMA } & \multicolumn{2}{c}{ Siswi SMP } & \multicolumn{2}{c}{ Total } \\
\cline { 2 - 7 } & Jumlah & $\mathbf{\%}$ & Jumlah & $\mathbf{\%}$ & Jumlah & $\mathbf{\%}$ \\
\hline Tidak ada & 5 & 4,7 & 4 & 3,8 & 9 & 8,5 \\
Nyeri Perut & 45 & 42,8 & 41 & 39,0 & 86 & 82 \\
Pucat, pusing & 8 & 7,6 & 2 & 2 & 10 & 9,5 \\
\hline Total & 58 & 55,1 & 47 & 44,8 & 105 & 100 \\
\hline
\end{tabular}

\section{BAHASAN}

Dari hasil penelitian dengan menggunakan kuisioner yang dibagikan secara acak kepada 105 orang sampel yang terdiri dari 62 orang siswi SMA atau sekitar 59,0 $\%$ dari populasi sampel dan 43 orang siswi SMP atau sekitar $40,9 \%$ dari populasi sampel, didapatkan hasil sebagai berikut. Karakterisitik usia sampel yang diperoleh pa- da penelitian seperti yang digambarkan pada tabel 1 , dimana terdapat 15 orang siswi SMA atau sekitar 14,2 \% yang berusia antara 12-15 tahun dan terdapat 49 orang siswi SMP atau sekitar $46,6 \%$ yang berusia antara 12-15 tahun, jadi total sampel yang berusia antara 12-15 tahun yaitu berjumlah 64 orang atau sekitar $61 \%$. Sedangkan pada batasan usia antara 16-20 tahun terdapat 41 orang sampel siswi SMA atau sekitar 
$39,0 \%$ dan tidak terdapat siswi SMP pada batasan usia tersebut. Adapun yang terakhir pada batasan usia antara 21-24 tidak terdapat sampel. Tabel 2 menggambarkan distribusi pengetahuan haid berdasarkan usia menarche pada masing-masing sampel. Usia menarche dibagi kedalam enam variabel yaitu usia menarche 10 tahun, 11 tahun, 12 tahun, 13 tahun, 14 tahun, dan 15 tahun. Hasil penelitian yang dilakukan pada 105 orang siswi SMP dan SMA menggambarkan usia menarche terbanyak pada usia 11 tahun yaitu sebanyak 40 orang sampel atau sekitar 38,0\%, yang mengalami menarche 12 tahun sebanyak 31 orang atau $29,5 \%$, yang mengalami menarche 13 tahun sebanyak 14 orang atau sekitar 13,3\%, yang mengalami menarche 14 tahun sebanyak sembilan orang atau $8,5 \%$, dan yang mengalami menarche 15 tahun yaitu dua orang atau $1,9 \%$ dari populasi sampel. Cepat lambatnya usia menarche bergantung pada kondisi hormonal setiap individu. Selain itu faktor gizi memegang peranan penting yang dapat mempengaruhi siklus haid. Semmelweiss menyatakan bahwa, 100 tahun yang lalu usia gadis-gadis Vienna pada waktu menarche berkisar antara 15-19 tahun. Menurut Brown, menurunnya usia waktu menarche saat ini disebabkan oleh keadaan gizi dan keadaan umum yang membaik, serta berkurangnya penyakit menahun. Hasil penelitian pada tabel 3 menggambarkan distribusi Pengetahuan Haid berdasarkan lamanya perdarahan haid, yang terdiri dari empat variabel yaitu 2-5 hari, 5-7 hari, 7-9 hari, dan lebih dari sembilan hari. Penelitian yang dilakukan pada 105 siswi SMP dan SMA menggambarkan sebagian besar sampel yaitu sebanyak $47,6 \%$ atau 50 orang sampel mengalami waktu perdarahan haid selama 2-5 hari, 35 orang siswi atau sekitar 33,3\% mengalami perdarahan haid selama 5-7 hari, 16 orang siswi atau sekitar 15,2\% mengalami perdarahan haid selama 7-9 hari, dan yang mengalami perdarahan haid lebih dari sembilan hari yaitu berjumlah empat orang atau sekitar $3,8 \%$. Table 4 menggambarkan tentang distribusi pengetahuan haid berdasarkan pengetahuan siklus haid yang ditinjau dari panjangnya siklus haid. Penelitian pada 105 siswi SMP dan SMA menunjukkan 73 orang siswi yang terbagi dari 44 siswa SMA dan 29 siswi SMP atau sekitar 69,5\% mengalami siklus haid selama 21-28 hari, kemudian 20 orang sampel yang terdiri dari sembilan siswi SMA dan 11 siswi SMP atau sekitar 19,0\% mengalami siklus haid selama 29-32 hari, dan sembilan orang siswi yang terdiri dari empat siswi SMA dan lima siswi SMP atau sekitar $8,5 \%$ mengalami siklus haid selama kurang dari 21 hari, dan jumlah persentase paling se-dikit yaitu tiga orang siswi SMP atau sekitar 2,8\% mengalami siklus haid selama lebih dari 32 hari. Hasil penelitian pada tabel 5 menggambarkan keluhan-keluhan yang sering dirasakan oleh sampel selama masa perdarahan haid. Pada table ini menggambarkan keluhan sampel siswa SMP dan SMA yang didominasi pada keluhan nyeri perut yakni 86 orang atau sekitar $82 \%$ dari total jumlah sampel. Pada keluhan nyeri perut persentase antara responden siswi SMP dan SMA cenderung sama karena jumlah yang seimbang yaitu siswi SMA 45 sampel yang mengalami keluhan nyeri perut dan siswi SMP berjumlah 41 sampel yang mengalami nyeri perut. Sedangkan keluhan pucat dan pusing berada pada $9,5 \%$ dari total jumlah sampel atau sekitar 10 orang yang terbagi atas delapan siswi SMA dan dua siswi SMP, dan yang sama sekali tidak merasakan keluhan apa-apa selama haid yaitu berjumlah sembilan orang yang dibagi antara lima siswi SMA dan empat siswi SMP yang tidak mengalami keluhan apa-apa atau sekitar 8,5\% dari total jumlah sampel. Saat ini, status gizi merupakan salah satu faktor yang mempengaruhi pola siklus haid. Penelitian pada 3.500 pasien bagian obstetric dan ginekologi yang melakukan pengukuran besar temperatur, menunjukkan lebih dari 1000 data hasil pengukuran basal temperatur yang dimiliki oleh wanita yang mengalami minimal tiga kali siklus haid, ditemukan $80 \%$ menstruasi terjadi ketika kondisi kesehatan membaik. 


\section{SIMPULAN}

Dari hasil penelitian, ditemukan besarnya pengetahuan haid remaja di Manado yang diukur melalui pengetahuan umum tentang apa itu haid, usia menarche, siklus haid, dan keluhan haid yang dialami. Sebagian besar sampel mengeluhkan keluhan yang sama selama waktu perdarahan haid yaitu nyeri perut. Sebagian besar sampel berada pada usia produktif di masa remaja yang mengalami haid.

\section{DAFTAR PUSTAKA}

1. Situmorang A. Adolescent Reproductive
Health in Indonesia: A report 1. Prepared for STARH program Johns Hopkins University. Jakarta: Center for Communication Program, 2003.

2. Remaja Putri an Siklus Menstrusi [homepage on the Internet]. Nodate [cited 2011 Nov 8]. Available from: $\mathrm{http}: / /$ nitamedicastore.com/artikel_kese hatan/remajaputridansiklusmenstruasi/,

3. Pengetahuan remaja putri tentang pubertas [homepage on the internet]. Nodate [cited 2011 Nov 8]. Available from: http://ktiakbid.blogspot.ktiskripsi.com/2 011/11/pengetahuan-remaja-putri-masapubertas-tentang-dysmenore-di-

smp.html, diakses pada 8 November 2011 